Volume 8. No. 8, August 2020

International Journal of Emerging Trends in Engineering Research

Available Online at http://www.warse.org/IJETER/static/pdf/file/ijeter39882020.pdf

https://doi.org/10.30534/ijeter/2020/39882020

\title{
An Experimental Study of Pavement Quality Concrete for Rural Roads in India Using Plastic and Industrial Wastes
}

\author{
Karthik M ${ }^{1}$, Shashank V B ${ }^{2}$, Ajey Kumar V G ${ }^{3}$ \\ ${ }^{1}$ Assistant Professor, Dept. of construction technology \& management, DSCE,Bengaluru, \\ India.karthik-ctm@dayanandasagar.edu \\ ${ }^{2}$ M. tech Student Dept. of construction technology \& management, DSCE, Bengaluru, India. \\ shashank.bolbandi@gmail.com \\ ${ }^{3}$ JuniorResearch Fellow- ISRO Respond, Sri Venkateshwara College of Engineering, Bengaluru, India, \\ ajeyhosadurga@gmail.com
}

\section{ABSTRACT}

This study is carried out in two phases. Phase I is focused on production, utilization of two different categories of waste plastics namely High-density polyethylene (HDPE), Polyphenylene Ether (PPE) as coarse aggregate collected from landfills as a replacement to conventional coarse aggregates. The optimum replacement percent for the most suitable plastic aggregate from phase I is considered for phase II where in mineral admixtures Fly ash, ground granulated blast furnace slag (GGBS) and a composite of FLY ASH and GGBS are added for concrete mixes to replace $20 \%$ of ordinary Portland cement (OPC) and tested. Phase I results showed that at $20 \%$ replacement by both categories of plastic aggregates exhibited good fresh and hardened properties of concrete whereas PPE plastic aggregate mix showed better results comparatively. In phase II the workability is increased due to reduced unit water content. There was a growth of $12 \%, 18 \% 15 \%, 22 \%$ and $14 \%, 20 \%$ in compressive, flexural strength due the addition of Fly ash, GGBS, combination of FLY Ash and GGBS respectively. A noticeable increase in tensile strength, abrasion resistance and decrease in water permeability of all the mixes with mineral admixtures can be seen. The strength gained is credited to the free calcium hydroxide which is produced during the cement hydration which reacts with the additional production of hydrates of calcium silicate due to reactivity of silica with fly ash, GGBS and a result of continued pozzolanic reactivity with better Interfacial transition zone (ITZ) formation.

Key words: Industrial wastes, Recycled plastic coarse aggregate, Rigid pavements, Rural Indian roads, Sustainable, Waste management.

\section{INTRODUCTION}

India has a large network of the roads with around a length of 58.98 lakh kilometers [1]. In recent days the construction of rigid pavements is increasing in India due to its long life and low life cycle cost. The use of recycled, waste materials decreases the construction cost and the environmental pollution caused by using of virgin materials. Today, concrete is the most sought-after product by man in the world. Cement in excess of 7 billion $\mathrm{m}^{3}$ is produced each year which causes huge amount of water, air pollution and also uses large scale natural resources. Consumption of plastic in India is calculated to be around 13 MT per year and 9 MT plastic waste is produced annually according to the reports of central pollution control board, India [2]. In a bid to find a solution for the problems the research has led to the usage of industrial wastes, agricultural wastes and plastic wastes in the concrete as an alternative. $[3,4,5]$

The current study mainly focuses on testing workability, mechanical and durability properties of concrete for rigid pavements of rural roads which are usually designed for less load bearing capacity using waste products in concrete. The objectives of the study is to making rigid pavements for rural roads by using plastic wastes as coarse aggregates, industrial wastes such as fly ash and GGBS as partial replacement to cement so as to make the rural roads less expensive, more durable, environmentally friendly and sustainable by understanding the variations in the properties of M30 concrete with the their addition.

\section{MATERIALS AND METHODS}

This section of the paper discusses the procedures being conducted in the laboratory. The current study is done in two 
Karthik M et al., International Journal of Emerging Trends in Engineering Research, 8(8), August 2020, 4287 - 4292

phases. In the phase I M30 grade concrete for conventional mix was designed based on IS-10262:2009.The Three concrete mixture series were readied namely $\mathrm{CM}$ (Conventional mix) H10, H20, H30, and P10, P20, P30. In series H \& P HDPE, PPE coarse aggregate were respectively utilized asreplacement in part for virgin, natural coarse aggregates with varying replacement percentage of 10\%,20\% ,30\% by volumetric fraction. The mix which showed nearer values to the conventional mix was chosen for the phase II of the project. In phase II Fly ash, GGBS and a combination of both Fly ash and GGBS was used to replace $20 \%$ of OPC and these are named as P20A, P20B, P20C. Table 3displays the materials' proportions used in the study. no chemical admixtures added. Experimental procedures were carried out to find out the behaviour and property of the manufactured aggregates, properties of the concrete mixes in fresh and hardened state with the incorporation of waste plastic aggregates and mineral admixtures. [6,7]

\subsection{Materials utilized for the study}

\subsubsection{Cement}

Ultratech brand OPC grade 53 which confirmed to IS: 11269:2003 with specific gravity of 3.15 as ascertained in the laboratory is used throughout the study.

\subsubsection{Aggregates}

Virgin natural aggregates and recycled plastic in nature aggregates both of $20 \mathrm{~mm}$ down size were used in the experimental study and under the surface dry condition confining to the IS standards. Natural crushed granite stone was utilized as conventional coarse aggregate, and waste recycled plastics such as HDPE, PPE were independently used as recycled aggregates and are demonstrated below in Figure1, Figure2, Figure3.[8] Recycled waste plastic aggregates were produced by mechanical process. All the coarse aggregates' physical and mechanical properties is determined as per IS code 2386 (part III, IV) [10]. Table 1. Displays the properties of the natural and waste plastic aggregates. Manufactured sand of zone- II is used. The properties of M-sand are determined as per IS code 2386 (Part II) -1963 and are given in the Table 2. The results are in accordance with the limits specified in IS: 383-1970.
Table 1: Properties of HDPE, PPE and Natural aggregates

\begin{tabular}{|c|c|c|c|}
\hline Tests & HDPE & PPE & $\begin{array}{l}\text { Natural } \\
\text { aggregates. }\end{array}$ \\
\hline $\begin{array}{l}\text { Specific } \\
\text { gravity }\end{array}$ & 1.04 & 0.9 & $2.5-2.9$ \\
\hline $\begin{array}{l}\text { Water } \\
\text { absorption }\end{array}$ & 0.05 & 0 & $0.1-2 \%$ \\
\hline Bulk density & 540 & 490 & $1200-1750$ \\
\hline $\begin{array}{l}\text { Fineness } \\
\text { modulus }\end{array}$ & 6.82 & 6.92 & $6-6.9$ \\
\hline $\begin{array}{l}\text { Crushing } \\
\text { Strength }\end{array}$ & 2.4 & 0 & $<30 \%$ \\
\hline Impact Test & 0 & 0 & $<20 \%$ \\
\hline $\begin{array}{l}\text { Abrasion } \\
\text { Test }\end{array}$ & 0 & 0 & $<40 \%$ \\
\hline
\end{tabular}

Table 2: Manufactured sand Properties

\begin{tabular}{|l|l|}
\hline Tests & Results \\
\hline Specific gravity & 2.6 \\
\hline Water absorption\% & 1.5 \\
\hline Zone & II \\
\hline Bulk density $\left(\mathrm{Kg} / \mathrm{m}^{3}\right)$ & 1700 \\
\hline Fineness modulus & 2.56 \\
\hline
\end{tabular}

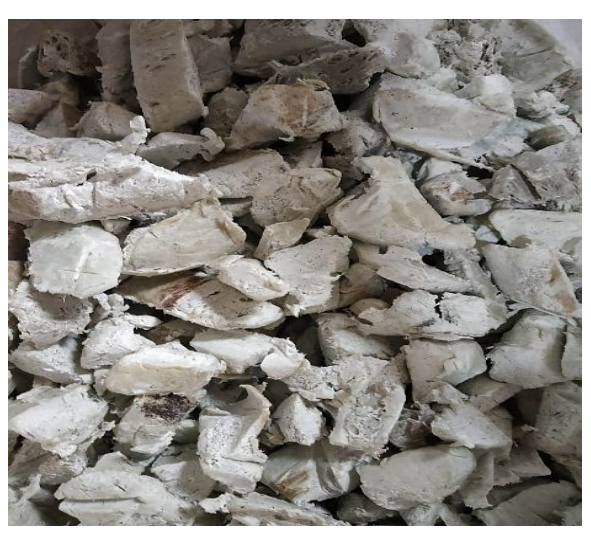

Figure 1: HDPE Aggregates 


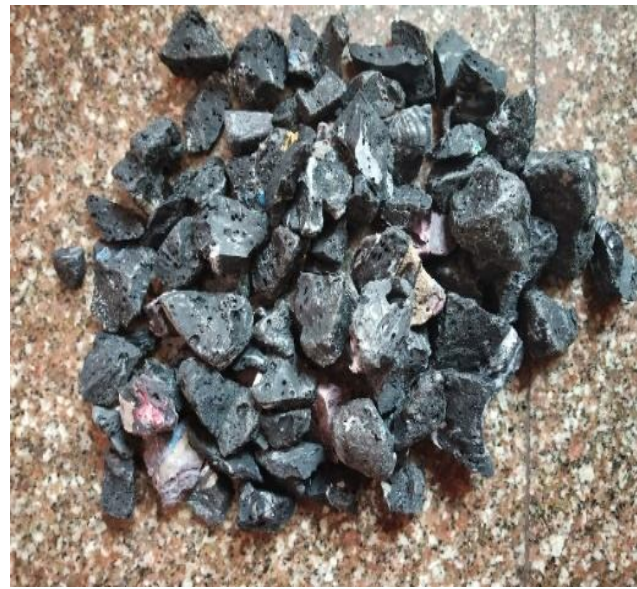

Figure 2: PPE Aggregates

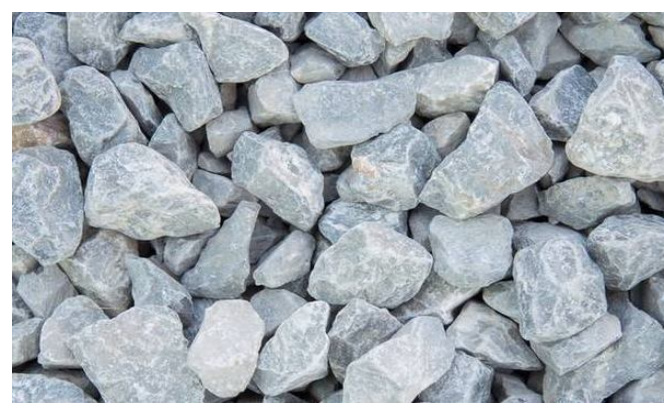

Figure 3: Virgin Natural aggregates

\subsubsection{Water}

Potable water is used in this study which is confirming to IS: 456-2000 for the Preparation of concrete and also for the purpose of curing the concrete specimens.

\subsubsection{Mineral admixture}

The Fly ash utilized in this study is procured from thermal power station, shaktinagar Raichur which when tested in the laboratory found to have specific gravity of 2.6 confirming to IS 3812 (Part 1): 2013. GGBS used in the study was branded and supplied by Jindal steel works with specific gravity of 2.9 confirming to IS 12089:1987

\subsection{Concrete Mix}

The mix proportion is prepared for concrete of M30 grade following the guidelines of IS 10262-2009, IS 456-2000 with of $38.25 \mathrm{MPa}$ as the target strength on curing of 28 days, the mix proportions obtained is $1: 1.6: 2.8$ maintaining a constant w/c ratio of 0.45 throughout the study. In the phase I of this study the quantity of cement, water and M-sand are unchanged for all the mix proportions. However only coarse aggregate content varied according to the replacement of waste plastic aggregates. In phase II only fine aggregate content was kept constant and all other constituent materials varied based upon the replacement levels. Coarse aggregates of the same grading were used for concrete mixes for better comparison. No plasticizers were used in preparing concrete mixes.

Table 3: Mix proportions for M30 concrete mixes $\left(\mathrm{kg} / \mathrm{m}^{3}\right)$

\begin{tabular}{|c|c|c|c|c|c|c|c|}
\hline $\begin{array}{c}\text { Mix } \\
\text { series }\end{array}$ & Cement & Fy ash & GGBS & Fine aggregate & Water & $\begin{array}{c}\text { Coarse } \\
\text { aggregates }\end{array}$ & $\begin{array}{c}\text { Waste Plastic } \\
\text { aggregates }\end{array}$ \\
\hline CM & 41.1 & 0 & 0 & 659.6 & 186 & 1131.66 & 0 \\
\hline H10 & 414 & 0 & 0 & 659.6 & 186 & 1018.5 & 44.75 \\
\hline H20 & 414 & 0 & 0 & 659.6 & 186 & 905.5 & 89.5 \\
\hline H30 & 414 & 0 & 0 & 659.6 & 186 & 803.72 & 134.2 \\
\hline P10 & 414 & 0 & 0 & 659.6 & 186 & 1018.5 & 39.5 \\
\hline P2O & 414 & 0 & 0 & 659.6 & 186 & 905.5 & 79.1 \\
\hline P30 & 414 & 0 & 0 & 659.6 & 186 & 803.72 & 118.2 \\
\hline P20A & 330.12 & 68.12 & 0 & 659.6 & 180 & 905.5 & 79.1 \\
\hline P20B & 330.12 & 0 & 76 & 659.6 & 182.5 & 905.5 & 79.1 \\
\hline P2OC & 330.12 & 34.06 & 38 & 659.6 & 181 & 905.5 & 79.1 \\
\hline
\end{tabular}

\section{RESULTS AND DISCUSSIONS}

\subsection{Study of fresh concrete}

\subsubsection{Study on workability}

Slump cone was used in this experimental study to test the workability of the concrete in accordance with IS: 1199-1959.The slump values were recorded from the top of slump cone.

In the Phase I the slump increases as the replacement by HDPE aggregates increases this is due to the smooth surface of HDPE aggregates. The slump reduced with increase in PPE aggregates replacement and this reduction is well expected because of porous texture of the aggregate which holds water from the mix thereby lowering the workability of mix. In Phase II the value of slump increased due the mineral admixtures addition because of decreased unit water content. Conventional mix exhibited workability of slump $60 \mathrm{~mm}$. The slump values within the range of $60 \mathrm{~mm}$ is acceptable as rigid pavements need less workable concrete. The other values of slump are tabulated in Table 4. Figure.4 depicts the slump values and the trend.

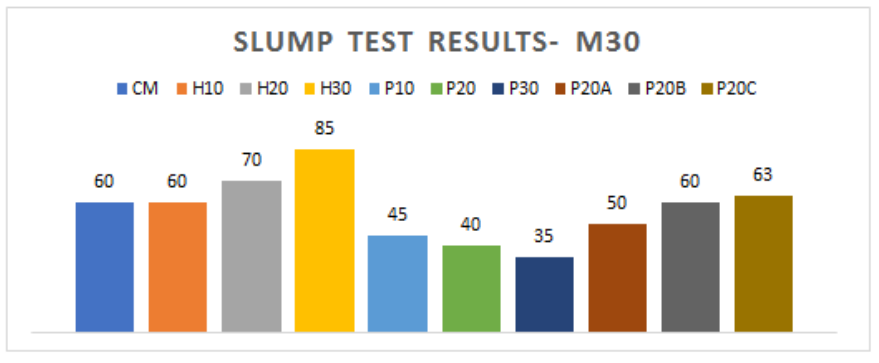

Figure 4: Slump test results 
Karthik M et al., International Journal of Emerging Trends in Engineering Research, 8(8), August 2020, 4287 - 4292

\subsection{Study on Mechanical properties of concrete mix}

To determine the compressive strength at 7,28days, flexural and split tensile strengths at 28 days of water curing in phase I and II the concrete specimens were subjected to destructive testing according to IS: 516 and IS: 5816. In Table.4the strength property parameters for compression, flexure and tension are tabulated.

\subsubsection{Compressive strength}

Concrete specimens of $150 \mathrm{~mm} \times 150 \mathrm{~mm}$ x $150 \mathrm{~mm}$ sized cubes were used to carry out the test at the laboratory as per IS: 516 to determine the compressive strength at 7,28days of curing period.

In Phase I the compressive strength of mixes reduced as compared to the conventional mix, with the increase of replacement values of plastic aggregates. The reduced strength was attributed to the weak bonding of plastic aggregates to cement paste which resulted in inferior ITZ. It was noted that at $20 \%$ replacement the strength was optimally nearer to the conventional mix or within the acceptable limits. In phase II mineral admixtures addition increased the strength of concrete due to its pozzolanic properties. Figure.5depict the strength at various replacement levels.

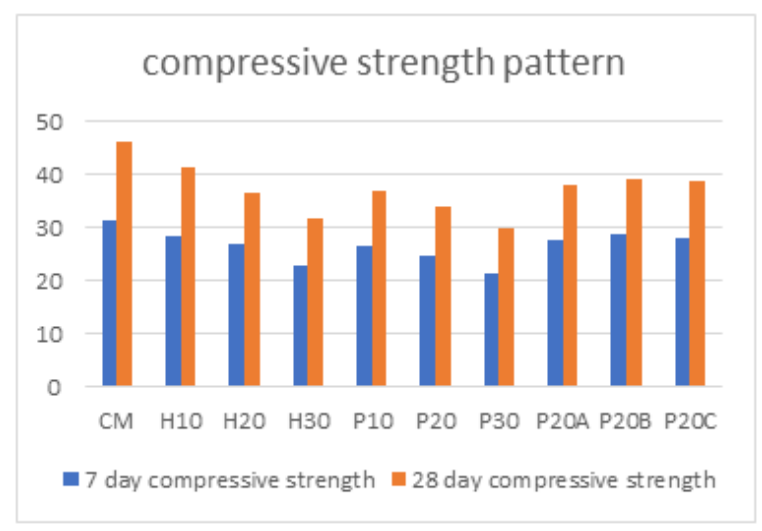

Figure 5: Compressive strength pattern

\subsubsection{Flexural strength}

Flexural strength of all the mixes are determined using hardened concrete beam specimens of size 100 X 100 X 500 $\mathrm{mm}$ as per IS: 516 . The strength patterns for flexural strength were observed to be similar to that of compressive strength in both Phase I \& Phase II. With increase in \% of replacement of waste plastic coarse aggregates flexural strength decreased. It was noted that PPE aggregates at $20 \%$ replacement gave flexural strength more than the minimum limit of 3.8Mpa [9]. The addition of mineral admixtures gave much higher flexural strength on par with the conventional mix. The results obtained are tabulated in Table. 4 and depicted in Figure.6

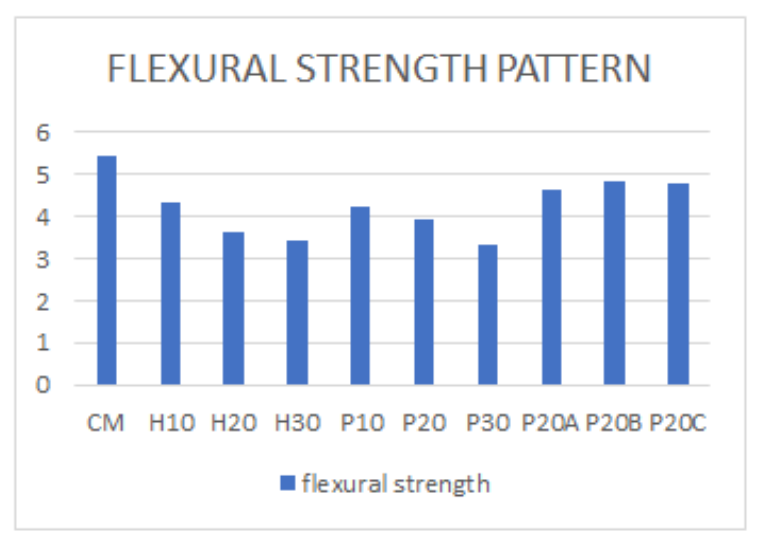

Figure 6: Flexural strength pattern

\subsubsection{Split Tensile strength}

Splitting tensile strength was determined by testing specimens of $150 \mathrm{~mm}$ dia $\times 300 \mathrm{~mm}$ size cylinders as per IS: 5816. It was observed that there was a decrease in tensile strength with increase in \% replacement of waste plastic aggregates, whereas addition of mineral admixtures resulted in an increase in tensile strength in Phase II. The results are tabulated in Table 4 and depicted in Graph Figure. 7

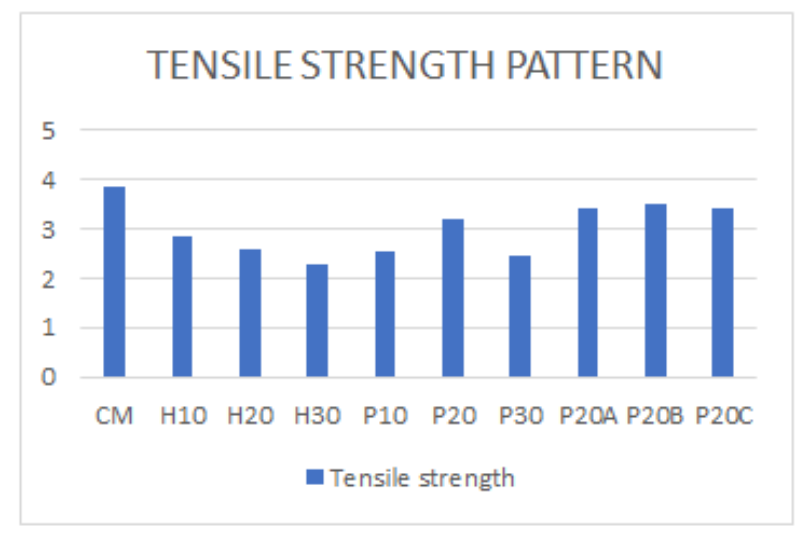

Figure 7: Tensile strength pattern

\subsection{Study on Durability properties of concrete mix}

The concrete specimens with mixes CM, P20, P20A, P20B, P20C were tested for its durability in Phase II of the study by conducting abrasion resistance test and sorpitivity test. The results obtained in the study for durability are shown in Table.5 
Karthik M et al., International Journal of Emerging Trends in Engineering Research, 8(8), August 2020, 4287 - 4292

\subsubsection{Abrasion}

The abrasion resistance for concrete specimen under Phase II were investigated for CM, P20, P20A, P20B, P20C mixes using the sand blasting method as per IS $9284.100 \mathrm{~mm}$ cubical specimen was used to test after 28days of curing and dried. The loss of mass of the two separate impressions was taken as the loss due to abrasion of the specimen. It was observed that with addition of mineral admixtures the loss of mass of the specimen due to abrasion was less compared to the conventional concrete. GGBS performed slightly better compared to fly ash and the combination of both fly ash and GGBS. This is attributed to the strong formation of ITZ and the ultra-finer particles of the mineral admixture making the paste stronger [10]. The abrasion resistance of the mixes is depicted is graph Figure. 8

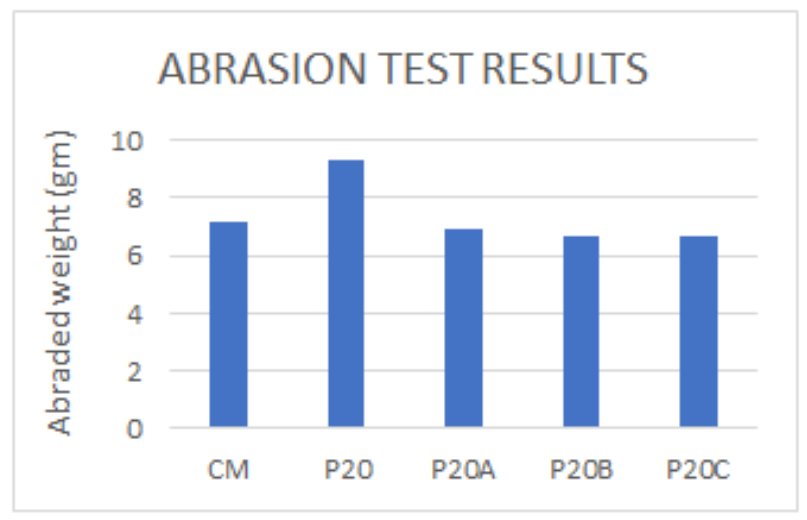

Figure. 8: Abrasion resistance pattern

\subsubsection{Sorpitivity}

An index of the transport of moisture into the unsaturated specimen through the action of capillary rise in the concrete specimen which is related to the durability of the concrete. The test is performed as per specifications of ASTM C1585. The specimen was dried in oven and was coated with waterproof epoxy raisin paint on the outer sides so that movement of water is through capillary action only. The quantity of water absorbed in 30 minutes was measured by the source of increase in weight of the concrete specimen [10]. It was observed that P20 mix exhibited higher sorpitivity coefficient than CM mix as the pores are larger due to weak bonding of plastic aggregates and the cement paste, with the addition of mineral admixtures the sorpitivity co-efficient of the specimen decreased drastically. This can be justified as mineral admixtures gives a dense paste structure which in turn reduce the pore size. The trend for coefficient of sorpitivity recorded is shown is Figure. 9

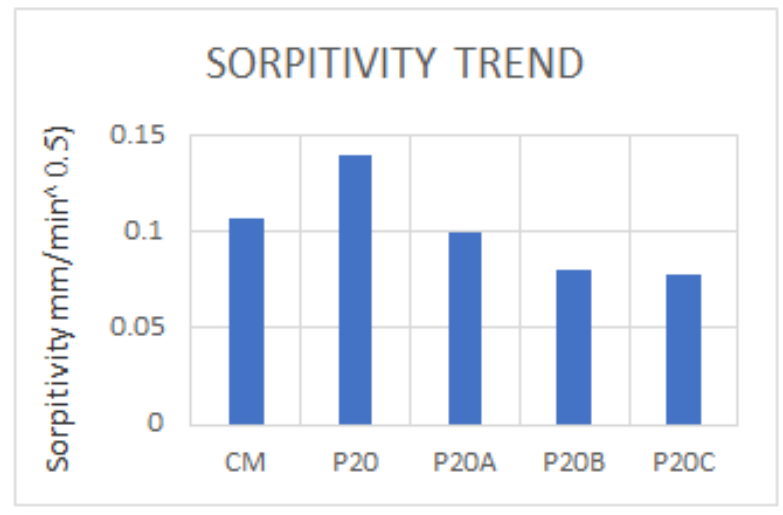

Figure 9: Sorpitivity trend

Table 4: Workability, mechanical properties of M30 concrete mixes

\begin{tabular}{|l|l|l|l|l|l|}
\hline Mix & $\begin{array}{l}\text { Slump } \\
\text { values } \\
(\mathrm{mm})\end{array}$ & $\begin{array}{l}7 \text { days avg. } \\
\text { Compression } \\
\text { strength } \\
(\mathrm{MPa})\end{array}$ & $\begin{array}{l}\text { 28 days avg. } \\
\text { Compression } \\
\text { strength } \\
(\mathrm{MPa})\end{array}$ & $\begin{array}{l}\text { 28 days } \\
\text { avg. } \\
\text { Tensile } \\
\text { strength } \\
(\mathrm{MPa})\end{array}$ & $\begin{array}{l}\text { 28 days } \\
\text { avg. } \\
\text { Flexural } \\
\text { strength } \\
(\mathrm{MPa})\end{array}$ \\
\hline CM & 60 & 31.5 & 46.0 & 3.83 & 5.43 \\
\hline H10 & 60 & 28.4 & 41.3 & 2.85 & 4.34 \\
\hline H20 & 70 & 27.0 & 36.7 & 2.59 & 3.62 \\
\hline H30 & 85 & 23.0 & 31.8 & 2.26 & 3.40 \\
\hline P10 & 45 & 26.6 & 37.0 & 2.54 & 4.20 \\
\hline P2O & 40 & 24.6 & 33.9 & 3.20 & 3.9 \\
\hline P30 & 35 & 21.5 & 29.8 & 2.44 & 3.30 \\
\hline P20A & 50 & 27.5 & 37.96 & 3.4 & 4.7 \\
\hline P20B & 60 & 28.92 & 39.2 & 3.5 & 4.8 \\
\hline P20C & 63 & 28.04 & 38.64 & 3.4 & 4.75 \\
\hline
\end{tabular}

Table 5: Durability Properties of concrete mixes in Phase II

\begin{tabular}{|l|l|l|}
\hline Mix & $\begin{array}{l}\text { Sorpitivity } \\
\text { values }\left(\mathrm{mm} / \mathrm{min}^{0.5}\right. \\
\text { ) }\end{array}$ & $\begin{array}{l}\text { Abrasion } \\
\text { values(gm) }\end{array}$ \\
\hline CM & 0.107 & 7.2 \\
\hline P20 & 0.140 & 9.3 \\
\hline P20A & 0.100 & 6.9 \\
\hline P20B & 0.080 & 6.7 \\
\hline P20C & 0.078 & 6.7 \\
\hline
\end{tabular}

\section{CONCLUSION}

The specific gravity, absorption of water of recycled plastic coarse aggregates is very low when compared to the conventional natural aggregates. Fineness modulus and bulk density were found to be within acceptable range. Flakiness index, elongation index and angularity number 
Karthik M et al., International Journal of Emerging Trends in Engineering Research, 8(8), August 2020, 4287 - 4292

were found to be within the code specification. Impact crushing and abrasion values of recycled plastic aggregate within the acceptable range as per code provisions to be used in concretes for both wearing and non-wearing surfaces.

In phase I the workability of concrete tends to decrease with increase in the replacement \% of PPE plastic coarse aggregates and vice versa for HDPE plastic aggregates due to its smooth texture. The mechanical properties of concrete made with waste plastic aggregates were inferior to that of the conventional mix concrete with natural aggregates.

At $20 \%$ replacement of waste plastic aggregates showed optimum results, whereas PP aggregates showed slight better results that HDPE aggregates.In Phase I the reduced strength can be attributed to the weak bonding of aggregates to paste which resulted in poor internal transition zone (ITZ).

The addition of mineral admixtures improved the properties of to a greater extent. There was no much difference between Fly ash and GGBS added mixes, but GGBS showed slightly better results comparatively

In Phase II the increase in strength of the concrete mixes is the result of the increased pozzolanic activity of mineral admixtures and better ITZ formation. The durability of concrete with plastic aggregates is improved due to the dense paste formation, lesser voids by the addition of the mineral admixtures.

\section{REFERENCES}

1. Ministry of road transport and highways Govt of India.Annual report 2018-2019MORTH Publication.

2. Ministry of environment, forest \& climate change, Assessment and characterization of plastic waste generation in 60 major cities, Published by central Pollution Control Board, January 2015.

3. Ashwini Manjunath $B \mathrm{~T}$, Partial replacement of E-plastic Waste as Coarse-aggregate in Concrete.International Conference on Solid Waste Management,5IconSWM, Procedia Environmental Sciences Vol.35 pp.731 - 739, 2016. https://doi.org/10.1016/j.proenv.2016.07.079

4. MohdFakri Muda,Saffuan Wan Ahmad, Fadhluhartini Muftah, MohdSyahrulHisyamMohd Sani.Mechanical Behaviour of Mortar Made with Washed Bottom Ash as Sand Replacement.International Journal of Emerging Trends in Engineering Research.Vol.7, pp.268-275,2019.

https://doi.org/10.30534/ijeter/2019/09792019

5. Latha MS, Naveen Kumar B M, RevanasiddappaMadihalli, Deepika R, Rudraswamy M P.Strength Characteristics of High-Performance Concrete using Bagasse Ash and Slag Sand.International Journal of Emerging Trends in Engineering Research.Vol.8 pp.2486-2489, 2020. https://doi.org/10.30534/ijeter/2020/45862020

6. A.H.L.Swaroop, K.Venkateswararao, P Kodandaramarao. Durability Studies on Concrete with Fly Ash \&Ggbs. International Journal of Engineering Research and Applications (IJERA) Vol. 3, Issue 4, 2013

7. Vallabuni Vinay Kalyan, P.Sandeep Chandra Mohammed Ibrahim. Study and Analysis of Rigid Pavements Using Fly Ash. International Journal of Innovative Research in Science, Engineering and Technology. Vol. 7, Issue 2.2018

8. Fahad K. Alqahtani, M. Iqbal Khan, GurmelGhataora and Samir Dirar,Production of Recycled Plastic Aggregates and Its Utilization in Concrete.Journal of Materials in Civil Engineering, ASCE, ISSNpp.0899-1561. 2015

9. IRC SP:62-2014 Guidelines for design and construction of cement concrete pavements for low volume roads. Published by Indian Road Congress,New Delhi. 2014

10. Abhishek Jindal, G.D. Ransinchung R.N Behavioural study of pavement quality concrete containing construction, industrial and agricultural wastes. International Journal of Pavement Research and Technology vol.11 pp. 488-501. 2018 https://doi.org/10.1016/j.ijprt.2018.03.007 